\title{
Remembering "the blackfellows' dam": Australian Aboriginal water management and settler colonial riparian law in the upper Roper River, Northern Territory
}

\author{
M. Barber ${ }^{a}$ and S. Jackson ${ }^{b}$
}

\begin{abstract}
Using newly recovered and collated sources, we investigate the extent of pre-colonial and colonial Aboriginal weir construction in the upper Roper River, and we analyse a 1946 court case which considered the practice in the context of colonial pastoralism. Aboriginal people have built these temporary weirs at key locations since pre-colonial times to dam and divert the river flow, creating shallow lagoons that attract and retain key food species. The area subsequently became Elsey Station, the setting for the famous Australian novel, "We of the Never Never". This embedded the area and its inhabitants in the national consciousness and Aboriginal people provided crucial pastoral labour for the station. Station management encouraged weir construction from the $1920 \mathrm{~s}$ as the structures reduced cattle losses in the dry season, but a downstream pastoralist complained of inhibited water flow and took legal action. The resulting case is probably the first legal engagement with Aboriginal water and riparian management in Australia and the judgment overtly acknowledged weir construction as an Aboriginal practice that 'had been in existence from time immemorial.' However, non-Aboriginal pastoralists' role in enabling and amplifying weir construction saw the case listed and classified as a pastoral riparian dispute - effectively as an issue of non-Aboriginal settler colonial law - rather than as an Aboriginal, colonial and/ or intercultural practice. As a result, the weirs were outlawed as a riparian law violation and the case has therefore remained largely unreferenced in the subsequent literature on Aboriginal resource rights. In this paper, we detail the historical circumstances of the case, Aboriginal involvement in it, and how it has been recollected and interpreted in subsequent local and oral historical accounts. We highlight the importance of local agency, local resistance, and Aboriginal political priorities in Aboriginal accounts, as well as broader processes of historical suppression and memorialisation.
\end{abstract}

\section{Key Words}

Indigenous water rights, dam, native title, pastoral history, memory

\footnotetext{
${ }^{\mathrm{a}}$ Land and Water Flagship, CSIRO, Brisbane. Marcus.Barber@csiro.au. Tel +617 33835519

${ }^{\mathrm{b}}$ Australian Rivers Institute, Griffith University, Nathan, Queensland. Sue.Jackson@griffith.edu.au
} 


\section{Introduction}

Historical pasts are continually reconfigured and recreated by intertwined processes of forgetting and recollection, suppression and rediscovery, allowing them to reflect and legitimate current realities and as well as enable potential futures. Over the past 40 years, historical assessments of the colonisation of Australia and its impacts on Aboriginal people have undergone considerable evolution. This evolution has encompassed topics such as: the extent and severity of colonial frontier violence and how its' reporting was publicly minimized; ${ }^{1}$ the impacts of dispossession and resource appropriation on existing patterns of Aboriginal resource management and Aboriginal lifeways; ${ }^{2}$ Aboriginal adaptations to new ways of life, such as pastoralism; ${ }^{3}$ and more refined accounts of colonisation processes, notably the distinction between colonial subjugation and exploitation and settler colonial exclusion or removal. ${ }^{4}$ These historical reassessments have both informed, and been informed by, high profile developments in wider social, political, and legal domains - public protests, referenda, legal decisions, legislative initiatives and formal acknowledgements of past wrongs by government leaders and parliaments. These events, and the historical work that has supported them, have involved overt public engagement with the role of history and how the negative aspects of colonial pasts can be re-remembered and thereby redressed. ${ }^{5}$

Nevertheless, the colonial and settler colonial processes through which Aboriginal rights and interests were variously ignored, suppressed, occluded and/or dominated were often highly effective, and in many circumstances, recovering past traces is extremely difficult. Therefore, contexts in which both oral histories and detailed historical and legal records of past actions and encounters are found to exist (such as the upper Roper described here), are of great value. The juxtaposition and comparison of detailed oral and written records is not without its risks, particularly in an Aboriginal context, ${ }^{6}$ but the exercise can nevertheless reveal new knowledge of the past in the location of interest, suggest the complexities of other circumstances where such records do not exist, and enable analyses of what has been remembered and in what way, as well as what has been forgotten, and by whom. Retrospective analyses cannot reach back to recover an objective historical truth, but they can provide important perspectives on past moments of individual, collective and institutional memorialisation and suppression, and how those moments relate to current circumstances.

One important strand of historical (re)assessment of Australian colonisation involves the nature and extent of Aboriginal involvement in the pastoral industry. Analyses of Aboriginal roles in pastoralism encompass the range of contemporary forms of history, notably general regional histories ${ }^{7}$ and more specific accounts prioritising Aboriginal oral narratives from particular locations. ${ }^{8}$ The northern pastoral industry is interesting because it clearly demonstrates the significance of material and economic drivers in shaping colonization processes - the settler colonial deprivation of formal rights and access to resources (particularly land and water) was combined with the colonial subjugation and exploitation of Aboriginal labour necessary to extract profit from such marginal lands. Indeed, following early violence and coercion, ${ }^{9}$ this combination of colonial and settler colonial forms was more in the nature of an interdependency - Aboriginal exclusion from the benefits of resources 
relied on permanent non-Aboriginal presence, which in turn relied on the exploitation of a 'pacified' Aboriginal labour force, at least until a combination of wage increases, mechanization, and land use changes rendered such a labour force redundant. ${ }^{10}$ Similarly, despite recent attempts at various kinds of restitution, notably in the form of land rights legislation, this colonial history continues to shape contemporary Aboriginal lives, as well as political debates about co-existence of indigenous customary and settler colonial property rights. ${ }^{11}$ Yet past and ongoing involvement in the cattle industry is also a source of pride for Aboriginal people, as well as a crucial means by which attachments to important landscapes were and are maintained. ${ }^{12}$ Although predicated on a history of colonial domination and exploitation, the history of shared work by Aboriginal and non-Aboriginal industry participants can provide a source of commonality across cultural and colonial barriers ${ }^{13}$ as well as the potential for direct intercultural collaboration on matters of mutual interest. ${ }^{14}$ Although it was economically 'peripheral' to Australian primary production volumes and occurred relatively late in Australian colonization, the history of the northern industry remains a useful means of interrogating colonial and settler colonial pasts. ${ }^{15}$

This paper is part of a series of publications from the upper Roper River focused on Aboriginal water values, rights and interests, on traditional techniques and purposes for water management, on contemporary water planning, and on intercultural pastoral history. ${ }^{16}$ The current paper focuses on the dispute over weir construction at Elsey Station during the 1930s and 1940s, Aboriginal involvement in that dispute, and how it was variously remembered and forgotten in subsequent decades. This dispute has interesting implications for legal and political history which will be investigated in far greater detail in a forthcoming publication (but see Burdon et al. in this volume for a general treatment of Aboriginal water rights). The emphasis here is on the relationship of history and memory in the dispute. Jeannie Gunn's early pastoral memoir 'We of the Never-Never ${ }^{17}$ established Elsey Station as a place of national historical interest, and encouraged an overt historical consciousness in some of its inhabitants. The weir dispute is recalled locally and has been the subject of occasional brief description in published accounts, but it has never been systematically investigated until now. The collation of scattered existing sources combined with newly located archives and field interviews enables the general 're-remembering' and rediscovery of the weir story, enabling commentary on the local ambiguities and interconnections of colonial and settler colonial processes, the role of Aboriginal actors in colonial contexts, as well as on cross-cultural processes of memorialisation and suppression. ${ }^{18}$

\section{Study site, methods and sources}

Northern Australia has a monsoonal climate and a correspondingly variable river flow pattern. In the wet season water is abundant, but in the mid-late dry season many rivers are reduced to nonflowing pools and this makes permanently flowing, groundwater-fed rivers such as the Roper River (Figure 1) of particular ecological and social significance. ${ }^{19}$ The upper Roper has a very flat topography and two important consequences are relevant here - it causes the river to braid into smaller channels, and enables small obstructions of wood and paperbark to be built at strategic points in those channels to flood wide areas to shallow depth and thereby provide significant additional aquatic habitat. The Roper weirs variously saturated the soil, reduced and/or redirected water flow across the floodplain, shifted water from the main channel down alternative side 
channels to widen the geographic footprint of the river itself, and created and/or augmented large shallow lagoons which further sustained animals and aquatic plants.

The main Aboriginal language groups in the focal area (Figure 2) are the Mangarrayi people (associated with Jilkminggan and Elsey Station) and the Yangman people (associated with the town of Mataranka). Considerable colonial violence complicated life for these language groups, ${ }^{20}$ but they have nevertheless been able to continuously occupy at least of a proportion of their traditional lands, and Aboriginal people now represent approximately $70 \%$ of the total combined population of the Mataranka and Jilkminggan area of approximately 900-1000. The frequency and extent of subsistence hunting has diminished due to the presence of alternative food sources and transport and access restrictions, ${ }^{21}$ but hunting nevertheless remains an important supplement to purchased food for Aboriginal people and retains other values as an activity and for its products. ${ }^{22}$

In general, non-Aboriginal pastoral relations to land emphasized economic returns rather than affective relations and notions of stewardship, but the latter are reported in studies of northern pastoral values. ${ }^{23}$ Elsey Station was first stocked in the 1880 s and was originally much larger than its current area of $7500 \mathrm{~km}^{2}$, incorporating downstream stations, what is now the town of Mataranka and the area of Elsey National Park (Figure 2). Owned by members of the Thonemann family in the decades of the weir dispute, the national and historical profile derived from Gunn's early memoir has been further augmented over time by newspaper articles, books, films, national museum exhibits, and a royal visit. ${ }^{24}$

Elsey Station is now in Aboriginal hands following a successful claim during the 1990s under the Aboriginal Land Rights Act (1976). The research upon which this paper is based involved archival, interview, and site visit components ${ }^{25}$ and complemented the first formal water planning process for the upper Roper River area. ${ }^{26}$ The archival sources located are particularly rich and include several published accounts: Gunn's book; ${ }^{27}$ the memoir of an Aboriginal woman from Elsey Station as written and edited by Elsey Station's then owner Harold Thonemann; ${ }^{28}$ a short history of Mataranka; ${ }^{29}$ an edited book of stories from local Aboriginal elders; ${ }^{30}$ and newspaper articles. ${ }^{31}$ Unpublished historical sources include government documents, ${ }^{32}$ private notes and correspondence from Elsey Station, ${ }^{33}$ court records, ${ }^{34}$ and photographs (Figures 3 and 4). Additional information was located in numerous works by the anthropologist and linguist Francesca Merlan ${ }^{35}$ and in reports completed for land claim processes. ${ }^{36}$

\section{The Roper weirs: subsistence and pastoral purposes}

The upper Roper is a rich riparian environment, and Gunn described the wide, shallow lagoons of the area (Figure 3) as 'glorious in flowering time with their immense cup-shaped crimson blossoms clustering on long stalks above great floating leaves' ${ }^{37}$ This environment is also highly seasonal, and from the mid to late dry season, water sources substantially recede in both number and extent, making the management of water and aquatic resources a significant issue. In the earliest located historical reference to the weirs, Gunn describes the circumstances at Red Lily Lagoon (Figure 2), the most important site for weir construction in the early colonial period. At this site, underlying rock formations make what Gunn calls a 'duck under', a shallow section which facilitates the creation of a diversionary blockage: 
Being so shallow and wide-spreading, the lagoons would dry up early in the "dry" were it not that the blacks are able to refill them at will from the river; for here the Roper indulges in a third "duck-under," so curious that with a few logs and sheets of bark the blacks can block the way of its waters and overflow them into the lagoons thereby ensuring a plentiful larder to hosts of wild fowl and, incidentally, to themselves. ${ }^{38}$

This was the original purpose of the structures: to 'ensure a plentiful larder' of fish, birds, reptiles, and aquatic plants. This purpose is regularly restated by a variety of subsequent protagonists in the weir story, and without it, the subsequent pastoral use for the weirs would not have arisen. As well as the weirs, Gunn also described seeing dying and dead cattle that had attempted to get to the receding waters of the dry season and had become trapped in the mud adjacent to them. Both overall cattle numbers and water quality were affected, and one mitigation strategy was for stockworkers to conduct regular patrols and rescue animals found in difficulty. Another strategy was to divert water to less boggy ground so the cattle could reach the water. It is unclear who first realised that the subsistence weirs could achieve the latter, but given that extracting bogged cattle was unpleasant and potentially dangerous, it seems likely that it was the Aboriginal workers themselves. This initially ancillary pastoral purpose for the weirs would eventually dominate public discussion of them, and become the primary source of contestation that led to legal proceedings.

\section{Controversy and justification}

From the 1920s, that contestation involved a range of identifiable individuals, with the key Elsey Station protagonists being Aboriginal spokesperson Elsey Dick, pastoral lessee Harold Thonemann and station manager Harold Giles. Resistance to weir construction was based on claims that the weirs impaired downstream water supply, and came predominantly from various operators of Roper Valley Station, particularly the key lessee from the 1930s onwards, Thomas Holt. The complaints were made directly to Elsey Station as well as to relevant government authorities, and led to increasing attempts by Elsey Station residents to document and defend the weir construction practice. During the 1930s and 1940s, various government officials (water resources staff, police, and military engineers) inspected or investigated what they sometimes termed 'the blackfellows' dam. ${ }^{\prime 39}$ The majority either endorsed the value of the structures or minimized their significance and downstream impact. ${ }^{40}$ In 1938, the Administrator of the Northern Territory created a new Water Ordinance and soon after this, Elsey Station pastoralists began securing government permits under this Ordinance to construct the weirs. ${ }^{41}$ These applications were made and granted as required between 1938 and 1945. The permits, and the history of government inspections, represented one of Elsey Station's key lines of defense in the subsequent court interrogation of the practice.

A second major line of defense during this period was to demonstrate that weir construction represented an ancient customary tradition that required legal recognition and protection. Elsey Station's lessee Harold Thonemann was particularly active in pursuing this, and a key document located during the current research is a transcript of a 1937 interview between Thonemann and Elsey Dick. Thonemann first established a timeline based on past station managers, then asked about the weirs themselves: 
Q: Why dam the Red Lily?

A: Him run wrong way right up Roper Bar. ${ }^{42}$

Q: When you dam him which way him run?

A: Long Wagon Lagoon.

Q: Why you want him run along Wagon Lagoon?

A: Make water run along Lagoon catchum fish.

Q: You catchum fish long Wagon Lagoon and long other holes?

A: Yes. Catchum fish when him dry.

Q: Your father catchum fish along Wagon lagoon?

A: Yes.

Q: What name your father?

A: Old Goggle Eye.

Q: Your father dam Red Lily?

A: Yes all about boy long time dam Red Lily to catchum fish.

Q: Alla same water Roper Bar?

A: Alla same water Roper Bar when big boy dam Red Lily and send him round Red Lily and Wagon Lagoon.

Q: How long you take dam Red Lily?

A: One day or two day.

Q: How many boy?

A: Big mob boy.

Q: How you dam him?

A: Stickum paperbark.

Q: Does it stop all the water?

A: Him holdum lot water, lot water run through paperbark.

Q: When rain comes what happens?

A: Him open em up and wash em away. Many a time got all day mendum. ${ }^{43}$

Elsey Dick asserts the purpose of the practice ('catchum fish'), that it was collectively undertaken ('big mob boy'), that those undertaking it were senior people ('big boy') and that it had a long, collectively-held history ('all about boy long time dam'). He goes on to note the semi-porous and temporary nature of the structures - they allowed some water through and were washed away by heavy rain - and that the weirs had no effect on the water at the Roper Bar lying downstream ('alla same Roper Bar'). From a present day perspective, perhaps the most striking thing about the above interview transcript is the title Thonemann gave to it: 'Black's water rights'. While Aboriginal waterrelated subsistence practices were already known from a number of locations by the $1930 \mathrm{~s},{ }^{44}$ this may be the first historical reference in colonial Australia which conceptualizes such river regulation practices in terms of water rights. It would be almost five decades before Aboriginal legal rights to inland waters were recognised as a result of the Mabo decision and subsequent passage of Commonwealth statute to protect native title. ${ }^{45}$

\section{Legal preparations}


Despite the government permits, the issue continued to fester and in 1945 the impacts on Roper Valley Station of a very intense dry season encouraged Holt to commence legal proceedings against Elsey Station. Key aspects of Elsey Station's defense preparations are accessible through correspondence between Thonemann (who resided in Melbourne), Giles at Elsey Station, and their lawyer Joseph Lyons. ${ }^{46}$ In June 1946, Thonemann outlined his initial position to Lyons, that weir construction is based on the 'ancient rights' of Aboriginal people as well as on the complementary rather than contradictory permits granted under the 1938 Ordinance:

The dam on this site has been erected by the blacks from time immemorial as you will see by enclosed. For many years it has been done by (Jungle) Dick (see my questions to him to follow). We claim on their behalf these ancient rights which may come under section 24 (e) of the Land [sic] Ordinance. Although we have asked permission to dam that should not invalidate their claim and it may be necessary to join (Jungle) Dick in the case. He would be a good witness I believe and is available. Giles tells me the blacks also dam the river further down and in fact in the river actually on the Roper Valley. It seems to me most important to stress the ancient rights of the blacks. Each year they desire to dam the river and only await our permission [original emphasis]. ${ }^{47}$

Thonemann strongly emphasized Aboriginal initiative in weir construction, assumed the main defendant would be Elsey Dick, and identified multiple sites where it occurred. His letter subsequently commented on the weakness of Holt's claim for damages, as from Elsey Station's perspective it was feed availability rather than water supply that was the primary causal factor in the cattle deaths experienced throughout the area during the previous season. Local stockworkers were interviewed about this issue in August $1945,{ }^{48}$ including George Conway, a non-Aboriginal stockman who had a long association with the area, and four Aboriginal men: Jabiru (Jaberoo) George, John Hodgson, Elsey Dick, and Sandy. George Conway confirmed that Roper Valley Station cattle died from starvation due to lack of feed and because the managers did not employ people to extract bogged animals, rather than from a lack of drinking water. Jabiru George also identified feed and bogging as the problems, as well as noting the impact on visitation by soldiers:

That dry time very bad for feed. We been knock off brand[ing] calf early, horse and cattle [were] too poor. I been go past Red Lily and River Channel. Cattle bog and die everywhere. Another year not bad like that. Two boys, two gin hard work pull cattle out bog. Boss can't let soldiers go Red lily too many poor cattle. Plenty water, only cattle die just the same. ${ }^{49}$

This passage also demonstrates the direct involvement of Aboriginal women (gins) in the industry, and versions of the weir story from senior contemporary women will be explored in more detail below. In his interview, John Hodgson also noted the poor season ('dry time been start early') and that grass not water was the problem. He names others involved in cattle extraction, including Dagan (a witness in the subsequent case), and another woman, 'Old Nellie'. Elsey Dick reemphasised the subsistence purpose stated in his previous interview ('Keep water full. Then plenty goose and duck come') and their pre-colonial origins ('when I been picanninny, ${ }^{50}$ I see old fellow black fellow show me'), as well as noting the high number of cattle losses in the previous dry season. Lastly, Elsey Dick states that a considerable number of weirs were being constructed and these included the main weir, but also ancillary weirs which prevented water flowing into reed beds that 
served no pastoral (or apparent subsistence) purpose, thereby redirecting additional water downstream onto Roper Valley Station.

Q: How many channels [do you block]?

Ans: Oh big mob.

Q: What for you stop big mob?

Ans: Oh, some go longa weed. We stop em go longa weed, then him make big water him Big River go Wagon Lagoon and Roper Valley. ${ }^{51}$

The fourth Aboriginal stockman interviewed, Sandy, further emphasized that water supply was not an issue, and that cattle were dying from starvation and only secondarily from bogging along the river. He would subsequently reiterate these points as a court witness (see below).

The interviews demonstrate direct Aboriginal involvement in Elsey Station's assertion of the precolonial origins of weir building and in establishing that Roper Valley's cattle losses were not due to water availability. Additionally, Elsey Dick's 1937 assertion about minimal downstream impact at Roper Bar had apparently been supported by the government investigations during the $1930 \mathrm{~s}^{52}$ Therefore, Elsey Station's case was based on an implied legal principle of co-existence between indigenous customary rights and settler rights to land and water - represented by the pre-historical origins and the government permits - and by the more pragmatic argument that there was no demonstrable downstream impact. Aboriginal people and their testimony were integral to the structure and content of these defense preparations, and it was presumed by the defendants that they would be equally important to the case itself.

However, as matters progressed towards the trial, the legal basis of the case began to change. The named defendants in Holt's legal action were Thonemann and Giles rather than Elsey Dick or other Aboriginal people, and letters from Elsey Station later in $1946^{53}$ reveal a greatly diminished focus on whether the weirs had their origins in pre-colonial Aboriginal practices and rights. The critical issue was now the particular circumstances in 1945 and specifically on: whether the government permits obtained by Elsey Station were valid; whether they had complied with the terms of those permits; and whether the dams constituted an illegal obstruction or a legal diversion that returned water to the river 'substantially undiminished in volume' as required by established water law. ${ }^{54}$

As a consequence, Elsey Station's proposed list of witnesses prioritized police and government officials, and, when listing Aboriginal witnesses, prioritized people who were specifically involved in dam construction in 1945 rather than senior spokespeople for the area. Other issues raised in the letters were to subsequently prove significant in proceedings - the limited experience of the government's local water resources staff; the possibility of calling an expert water engineer as a witness; and pre-existing animosity between the NT Administrator and the judge in the case. ${ }^{55}$ However, most important to note at this stage of preparations was the reduced Aboriginal involvement; discussions of Aboriginal customary water rights, or of the ancestry of Aboriginal practices generally, had been largely sidelined and the legitimacy of state power in ignoring, recognising, regulating, controlling, or outlawing weir construction was not a matter for consideration. It was colonial exploitation of weir technology that had brought the issue to the 
attention of the state, but it increasingly appeared that settler colonial processes would determine its legal fate. This tension was to be reflected in the content and conduct of the trial itself.

\section{The court case ${ }^{56}$}

The court hearings were held in Alice Springs in the Northern Territory from 14-18 ${ }^{\text {th }}$ October 1946. As a result of the changing orientation of the case, the participation of Aboriginal witnesses in the court process was very limited - in a 181 page transcript, ${ }^{57}$ testimony by the two Aboriginal witnesses comprises less than five pages, and those witnesses were only called on the second last day of hearings. When the first Aboriginal witness, Dagan, did provide unsolicited information to Elsey Station's counsel (Lyons) about pre-colonial Aboriginal practices, opposing counsel (Ward) objected:

MR. LYONS: What other blackfellow do alonga jungle?

DAGAN: Him block in the water before white man.

MR.WARD Objects.

MR. LYONS: What him bin do there, other blackfellow?

DAGAN: Do that for fish. Makem plenty water for duck. ${ }^{58}$

The objection may have been based on the comment representing hearsay rather than events witnessed by Dagan, or about it seeming rehearsed, but in either case, it nevertheless demonstrates the resistance to discussing the extended past duration of Aboriginal weir construction practices. Dagan was still able to refer to the subsistence basis of the weirs and subsequently spoke about weirs and log fish traps downstream from Red Lily Lagoon ('dam alonga jungle'), including at a place he calls 'new yard':

MR. LYONS: You savvy that one Old Dick?

DAGAN: Yes

MR. LYONS: Below where blackboy bin make dam alonga jungle, water bin come out then alonga main stream?

DAGAN: Yes.

MR. LYONS: Little bit further down alonga jungle, you savvy any blackboy bin makem any one dam there?

DAGAN: Yes, right down new yard.

MR. LYONS: What him bin do?

DAGAN: Him bin puttem dam there.

MR. LYONS: What for him bin puttem dam there?

DAGAN: For fish - killem turtle and fish, killem croc.

MR. LYONS: Make water dry a little bit?

DAGAN: Dry and cuttem hollow log, makem bit hole, and all fish go inside there.

MR. LYONS: Him bin makem dam like that another place alonga Roper?

DAGAN: Yes. ${ }^{59}$ 
Other than some further brief remarks about the downstream structures being temporary, the above represents the full extent of Dagan's testimony regarding Aboriginal purposes for and interests in slowing and/or diverting water flow. His cross-examination by Holt's counsel avoided any discussion of Aboriginal intentions, focusing entirely on Dagan's observations of water flows into the shallow reed beds adjacent to the site of the main weir. As Elsey Dick's comments in the 1945 interview above demonstrated, part of Elsey Station's argument was that the ancillary weirs they had constructed to prevent water reaching these beds and then evaporating from them had mitigated any effects of the main weir on downstream flow.

The other Aboriginal witness, Sandy, was asked some preliminary questions by Lyons about his previous employment with Holt and about fishing techniques he had seen and used. He was then asked about his observations of cattle in 1945:

MR. LYONS: What name that bullock - fat fella, poor fella?

SANDY: Poor fella.

MR. LYONS: What matter him bin poor?

SANDY: Poor grass, plenty water.

MR. LYONS: What name that grass?

SANDY: Grass bin no more grow; him bin dry.

MR. LYONS: What about that bullock - him bin thin fella?

SANDY: Yes, thin, poor fella; him bin drinkem water, him come back and die alonga dry place.

MR. LYONS: Blackboy alonga Roper Valley, they bin pullem bullock out alonga bog?

SANDY: No.

MR. LYONS: Not all same alonga Elsey?

SANDY: No.

MR. LYONS: Alonga Elsey they bin pullem out?

SANDY: Yes.

MR. LYONS: Mr. Holt bin sack you?

SANDY: Yes.

MR. LYONS: How many wet weather bin come up since then?

SANDY: One fella. ${ }^{60}$

Sandy confirms previous versions of the causes of cattle death in the previous season. Whilst what is recorded from the Aboriginal witnesses is of great interest, the restricted nature of the testimony is in stark contrast to the initial approach taken by Thonemann, who was keen to establish the precolonial origins of 'blacks' water rights' and their ongoing consistency and legitimacy with respect to colonial water law. It was not just the constrained testimony from Sandy and Dagan that indicated this, but also the fact that the highest profile Aboriginal spokesperson regarding this ancestry, Elsey Dick, was not even called as a witness, let alone listed as the primary defendant in the way that Thonemann had originally envisaged.

A larger and more diverse group of non-Aboriginal people were called on to give testimony in the case. These included: Giles and Thonemann as the defendants; Holt as the plaintiff; Holt's head stockman; police officers and an army engineer who had previously made inspections of the weirs; 
and a Sydney-based water engineer. During the course of the case, Elsey Station's counsel made a series of admissions that may also have affected the conduct of the trial and, most importantly with respect to Aboriginal involvement, the witnesses called after that point. These included that Aboriginal people had erected the main weirs and had received rations from the station, that the Elsey Station defendants had supervised weir construction, and that the ancillary weirs adjacent to the main weir that prevented water flowing into the reed beds were erected by 'Aboriginals as agents of the defendants' ${ }^{61}$ Relating to the last point, Giles had asserted in his evidence that when he first arrived at Elsey Station, the initiative to construct at least the primary weir had come from Aboriginal people - that he had initially 'told them to leave the river alone' but they had 'kept pestering' him until he relented. However the case was focused on the circumstances of 1945, not on where the initiative to construct the original weir had come from at Giles' arrival in the 1920s. The water engineer's subsequent expert witness testimony that evaporation from the lagoons created by the weirs would have had an impact on the downstream flow also appears to have been particularly influential. These issues - the focus on 1945, the restricted nature of Aboriginal testimony, the evaporation from lagoons created by the weirs, and the question of Aboriginal people acting as agents for Elsey Station, were all relevant to the final judgment.

\section{The judgment}

Justice Wells' judgment was based on a series of questions he posed to himself outlining the substantive issues, and the answers to those questions. In summary, his answers were that:

1) Aboriginal people were acting as the 'servants and agents of the defendants' in erecting and maintaining the dams;

2) The practice represented an illegal 'diversion' of the waters;

3) The practice diminished the flow of water onto Holt's land;

4) The licenses issued under the 1938 Ordinance were illegitimate, as the regulations to guide the permitting process had not been created;

5) Holt suffered damages, for which the defendants were liable. ${ }^{62}$

It was a comprehensive defeat for the Elsey Station defendants. Increasing the scale of the loss, Wells banned further weir construction without legitimately granted permits (something that would require significant additional regulation to mandate). The court had fully exercised its perceived power to govern and control water use and management to the detriment of Aboriginal interests. A case formally classified as a pastoral dispute had made the continuation and co-existence of an Aboriginal tradition far more problematic.

Amidst the apparent comprehensiveness of the defeat, two early paragraphs of the Wells judgment stand out, particularly when considered from a contemporary perspective where the relevant water ordinance has long since been superseded and certain specific property rights and recognitions for Aboriginal and Torres Strait Islander people now exist. At the time, these paragraphs acted as a prelude to the primary findings and substantive legal issues, but given the subject matter and their presumed ongoing status as an evidentiary finding by the court, they remain of considerable interest:

It has been for many years the custom of the natives, some at least of whom have been employed by the defendants, to dam or partially dam the Roper River where it flows through or 
adjacent to what is known as the Red Lily Billabong, just a few miles downstream from Elsey Station homestead, for the purpose, from the point of view of the natives, of maintaining during the dry season the level of the water in the billabong and conserving therein supplies of fish, and attracting to it quantities of ducks and geese which the natives catch and use for food purposes. From the point of view of the defendants, the maintenance of a high level in the billabong during the dry season is important for the reason that it enables cattle depasturing on Elsey Station to drink from the billabong on hard ground and thus avoids or minimises the danger of losses through bogging of cattle.

The evidence shows that the practice of damming the river by the natives for their own purposes had been going on for many years; that it was, in fact, an "old fellow black fellow" custom, or, to put it in legal terms, had been in existence from time immemorial. Whether or not the native practice was always carried out to the extent necessary to serve the purposes of the defendants is not clear, but apparently it was done to such an extent for some time prior to 1934, when the plaintiff first acquired an interest in Roper Valley Station. ${ }^{63}$

By 'putt[ing] it in legal terms', Wells explicitly recognizes and validates the legitimacy of the Aboriginal weir construction tradition, yet at the same time can see no room for its co-existence with settler property rights and so attempts to erase that tradition through a ban that was intended to be permanent. Some media coverage of the case noted both facets - acknowledging the subsistence origins of the weirs and the definitive loss for Elsey Station. ${ }^{64}$ Other coverage of the case reflects ongoing public interest in events at Elsey Station, but neglected any reference to Aboriginal subsistence. ${ }^{65} \mathrm{~A}$ moment of formal recognition of pre-existing customary Aboriginal interests by the colonial legal system also marked an apparently final point of settler colonial exclusion of those interests by that system. This exclusion encompassed measures to elide, ignore or suppress Aboriginal legal interests in the weirs in evidentiary terms as well as the active opposition to further weir construction.

\section{Aboriginal involvement}

Despite the way the case was conducted, and the final result, Aboriginal involvement in the weir dispute was significant. The archival and historical evidence demonstrates the subsistence origins of the weirs, Aboriginal initiative in ongoing weir construction, increasing significance of the weirs to Elsey Station's pastoral operations, and the overt participation and collaboration by Aboriginal people in the legal defense. In particular, Elsey Dick variously legitimated the pre-colonial nature of the practice via reference to his father and ancestors, asserted his own role (and that of other senior men) in construction, and spoke with authority about the consequences of the structures for downstream flow regimes. As well as constructing the weirs, Aboriginal people were visibly present at key moments in the weir story, such as police action to remove a weir in 1938 (Figure 4). Identifiable individuals were formally drawn in to legal preparations - Sandy, Jabiru George, and John Hodgson. Ultimately, Sandy was joined by Dagan as witnesses at the trial and this process would no doubt have involved additional undocumented preparations with the two men. The level of Aboriginal collaboration in defense of the practice has a range of broader historical and theoretical implications with respect to Aboriginal autonomy and intercultural collaboration which are explored elsewhere. ${ }^{66}$ What is important to note here is that alongside their key role as weir constructors and 
general mitigators of pastoral losses, the defense of the practice involved senior Aboriginal people for at least a decade prior to 1946.

\section{Histories and memories}

Recording the weirs as memory began early - Gunn's initial version is itself already a memoir, its present tense presuming a long history of past weir construction activity. Thonemann's first interview with Elsey Dick focused strongly on his memories and knowledge of the past - positioning the weirs within historical and pre-colonial memory was already perceived as crucial in 1937. No other protagonist left formal recollections, but the archival records about the case lodged by both Giles ${ }^{67}$ and government administrators of the time ${ }^{68}$ suggest an awareness of future historical interest in the dispute. In 1949, Thonemann provided a public version of the story that further promoted the longevity and ongoing autonomy of Aboriginal water management in particular and Aboriginal interests in general. ${ }^{69}$ This was an unusual position for a north Australian pastoral lessee to advocate for, even accounting for the economic benefit Elsey Station had originally derived from the weirs. In 1985, a second and quite different account of the weir dispute was generated. ${ }^{70}$ This acknowledged the Aboriginal subsistence origins of weir construction, but in contrast to Thonemann's version, prioritized pastoral issues and interests and did not name any Aboriginal actors, noting simply that in disputes, 'Aboriginal workers owed allegiance to the station for which they worked.'

The substantial variation in these two non-Aboriginal accounts raises the question of how the weir dispute is remembered by Aboriginal people themselves. No formal recollections from the Aboriginal people involved in the dispute were located, but a book of recollections of life at Elsey Station was published exactly 50 years after the case. ${ }^{71}$ This contained two separate versions of the weir story from descendants of those involved (Sheila Conway and Mary Nurniyn respectively) as well as editorial introductions to the stories by Merlan. In relation to these accounts, two key points will be highlighted - the purposes of the weirs and the degree to which actors and events in the historical record are re-prioritized in Aboriginal accounts.

The recollections encompass both subsistence and pastoral purposes for the weirs, but the pastoral purpose is particularly significant, both in terms of its priority with respect to subsistence and the general issue of Aboriginal initiative in weir construction. Merlan's editorial introduction to Mary Nurniyn's version of the weir story describes Elsey Dick as damming the river 'on behalf of Elsey Station' and that he 'was asked to do this by station manager Harold Giles, both to provide water in these places for the cattle, and to prevent them from bogging along the main river'. ${ }^{72}$ Merlan's interpretation is clearly influenced by local accounts that remain current and which emphasise Giles' role in the weirs. As well as this emphasis on Giles, Sheila Conway's version prioritises the role of Sandy (who was employed by Holt prior to being a case witness). In her narrative, Sandy is sent by Holt to investigate why there is no water. He does so and finds Aboriginal relatives who share food with him, and then he sees the weirs they have constructed:

'You've dammed it here!'

'We make a canal,' they said, poor things. We just shut it off for the fish!' 
'It [water] doesn't go downstream.'

In the afternoon he [Sandy] went, came out and told their manager [Holt].

'We sit here and sit here, I found the old people are damming the river and have made a canal!'

'So we're sitting here with no water!' the old man [Holt] said. ${ }^{73}$

This part of Sheila Conway's account prioritises the subsistence purpose and implies (through the voice of Sandy), that the weirs are the initiative of Aboriginal people. However she then goes on to tell the story of how Holt acted on the information Sandy had provided. In her version, Aboriginal people build the weirs but Giles ultimately controls them. He uses that control to discipline Holt, discipline which is required because Sheila Conway connects the weir story to another later court case involving Elsey Station and Holt in which Holt was charged and found guilty of shooting an Elsey Station bullock for meat. $^{74}$

That whitefella [Holt] sent telegrams every which way then. The policeman came and asked Kayko Giles. He [Holt] was stealing his cattle, he came from the east [Roper Valley] and was stealing his cattle. That one, and also from here [Elsey Station]. They were taking cattle off each other. That's not going on today. Then the old man went back. He sent telegrams to the police. The police picked up that old man. He took him to Alice Springs and they had court. And then what he [Giles] said was,

'You can't keep on taking my cattle. If you take them, I'll close off the water for good!'75

The 1949 cattle theft case involved a single animal, but events at Elsey Station were still of sufficient interest that it garnered southern media attention. ${ }^{76}$ Justice Wells presided again and in finding against Holt he acknowledged the 'old feud' between Roper Valley and Elsey Station. ${ }^{77}$ This hostility was apparently a sufficiently intense and long-lasting element in local pastoral relations that it occupies a pivotal place in local memory - the fact that the cattle theft case occurred three years after the weir case, and that it involved a new operator at Elsey Station, William Crowson, rather than Giles, was not as important in Sheila Conway's recollections as making a direct connection between the disputes. Once the temporal ordering disappears from the oral accounts passed on during the intervening decades, her version provides a sensible explanation for both events and the motivations behind them. It is even more sensible given that cattle were regularly being appropriated across property boundaries in the area prior to $1949 .{ }^{78}$ Sheila Conway gave a second version of the story as part of the current research that confirmed her 1996 interpretation: 'that's why that old feller [Giles] been saying to people to shut 'im off [make the dam], making them [downstream cattle] perish. Because him [Holt] going too far, you know, stealing cattle. ${ }^{79}$ In both accounts, Giles plays a crucial role.

Although not incompatible with the primary initiative for construction coming from Giles, Nurniyn's version in the same volume prioritizes the role of her own father, Elsey Dick, and identifies cattle welfare as the primary purpose:

That whitefella came, Mr Holt, they used to call him 'rock wallaby'. He came and asked my father.

'Why are you blocking off the water?'

My father said, 'I'm blocking off the water for our cattle.' 
'I want the water to flow downstream too,' he [Holt] said.

[Elsey Dick said]: 'Big Red Lily and Little Red Lily should fill up so it doesn't get muddy. So the cattle don't bog.'

[Holt] just came and asked my father. He asked your two grannies. ${ }^{80}$ He asked them and they knocked him back. 'We block the water for our cattle.' He went back to Roper Valley. ${ }^{81}$

For Mary Nurniyn, the weirs have a pastoral purpose, but they are controlled by Aboriginal people to the point where it is her father Elsey Dick who rejects Holt's request rather than Giles, the police, the legal system or other government authorities.

\section{Discussion}

When compared with one another and the historical record, the Aboriginal versions of the weir story from 1996 seem contradictory in terms of who is 'in control', yet there is one striking similarity between them - the complete absence of the negative court decision. In one version, Giles is given primacy as the actor responsible for determining if the weirs are built (even after the court case has happened), and in the second, the Aboriginal protagonists reject Holt's request and the legal case is not even mentioned. Justice Wells vanishes entirely from the oral histories of these two women they ignore or marginalise his judgment in a manner that parallels the way Wells himself ignored or marginalized Aboriginal evidence. Neither woman was an adult at the time of the case, and for Nurniyn, ignoring a process that deprioritised her father's authority to the point where he was not asked to formally participate in it is understandable. Others with close ties to the case's main Aboriginal protagonists remember the story differently - for example as a legal process that threatened potential incarceration for its Aboriginal participants. ${ }^{82}$ Nevertheless, the Aboriginal accounts generally attach a lesser importance to the court process for a range of reasons, not least that Wells' ban was only partially effective - collaborative weir construction continued on an adjacent station after $1946 .{ }^{83}$ The apparently definitive settler colonial exclusion of Aboriginal interests appears far more ambiguous 50 years later, diminished and deflected by a combination of pastoral economic expediency on adjacent stations and reassertions of local agency.

As has been noted elsewhere on the Roper, ${ }^{84}$ history is continually reconfigured and reorganised into narrative patterns that make sense of underlying past and present relationships and that reinforce local legitimacy. In this case, the weirs are depicted as either being built in response to Holt's cattle theft in the ongoing feud between Elsey Station and Roper Valley Station, or they represent Aboriginal agency against the colonizers as Elsey Dick exercises his power to reject Holt's requests. Although it first appears that the amplification of Giles' role by Sheila Conway and others minimises the role of Aboriginal people, emphasising non-Aboriginal initiative in weir construction and the subsequent dispute may have aided the deflection of initial responsibility for the 1946 ban within the local Aboriginal community. From this perspective, it somewhat counter-intuitively demonstrates the power of local intra-Aboriginal political positioning in depicting colonial circumstances - sufficiently important that de-emphasising Aboriginal control is a favourable option in recalling the past. The conflation of the two court cases further justifies that position, 
contextualising the origins of the weir dispute within the ongoing station 'feud' and providing an additional motivation for Giles to act. Memories of the weir dispute reflect key patterns and priorities in local colonial relationships, and the primacy of local control and local experience over more formal and institutional, but also more distant, forms of settler colonial power and authority.

The fact that non-Aboriginal pastoralists encouraged, enabled, and/or augmented weir construction, under a local model of co-existence, no doubt contributed substantially to the initially supportive state and institutional responses to the practice that occurred in the 1930s. However, this involvement by non-Aboriginal people as collaborators with shared interests also appears to have enabled the 1946 occlusion within the legal system of the Aboriginal people and interests that were integral to weir construction. Despite the clear pre-colonial origins of the underlying practice, it became possible to characterize the dispute as riparian and pastoral, rather than customary. As a result, settler colonial law was able to acknowledge ancient custom in passing, but unable to recognize the agency of Aboriginal people, nor consider their co-existing customary practices as rights worthy of recognition and protection. From a $21^{\text {st }}$ century perspective, the processes involved in the 1946 case suggest the avoidance or suppression of what in the future could and would become 'legal' facts about Australian history and Aboriginal land and resource rights, including practices that constitute incidents of native title. ${ }^{85}$

Although in large part this suppression reflected longstanding settler colonial legal and institutional constraints, local protagonists still played an active role in it in 1946. Wells' history of negative findings against Aboriginal people and interests has now been well documented. ${ }^{86}$ In this instance he chose not to legitimise the already acknowledged ancestry of weir construction as an ongoing instance of Aboriginal resource rights based in common and customary riparian law, as Thonemann had originally advocated. Nor does he openly canvass a compromise position which would prevent major unlicensed weir construction for pastoral purposes, but validate ongoing Aboriginal weir construction for subsistence purposes. The case was classified, listed, prepared, conducted and judged in ways that minimised Aboriginal involvement and its subsequent significance for matters of Aboriginal resource rights.

This intentional suppression at the time subsequently enabled a wider, less intentional process of institutional forgetting of this key aspect, such that Wells' evidentiary finding of the authenticity of Aboriginal tradition remained dormant in Australian legal history. The case described here has remained unreferenced in legal analyses of Aboriginal and Torres Strait Islander natural resource management and/or water resource rights ${ }^{87}$ and is not mentioned in Northern Territory cases where the extent of consistency between exclusive native title rights to the ownership and use of water have been adjudicated. ${ }^{88}$ The Roper River weir case now appears to represent the earliest located legal consideration of Aboriginal water resource management practices yet found, but one which has remained disconnected from legal tradition because of settler colonial processes of classification and suppression. Australia is considered to be a nation that has been late to recognize indigenous water rights relative to other settler colonial nations such as the USA and Canada. ${ }^{89}$ Australian native title law now commonly recognises Aboriginal and Torres Strait Islander rights to take and use water for personal, social, domestic and cultural (but not commercial) purposes without the need for a license. ${ }^{90}$ This makes it both timely and useful to re-remember the Roper weir controversy, re- 
Author's pre-print copy published in Settler Colonialism 2015

describe Aboriginal involvement in it, and re-analyse how it has been variously recollected and forgotten in subsequent decades.

\section{Acknowledgements}

We thank the Aboriginal and non-Aboriginal research participants in this study for their invaluable participation. Funding support was provided by the Water for a Healthy Country Flagship of the CSIRO and the Northern Australia Water Futures Assessment (NAWFA) and authorized through the Northern Land Council (NLC). We thank multiple reviewers for their comments on this research and accept responsibility for any remaining errors. 


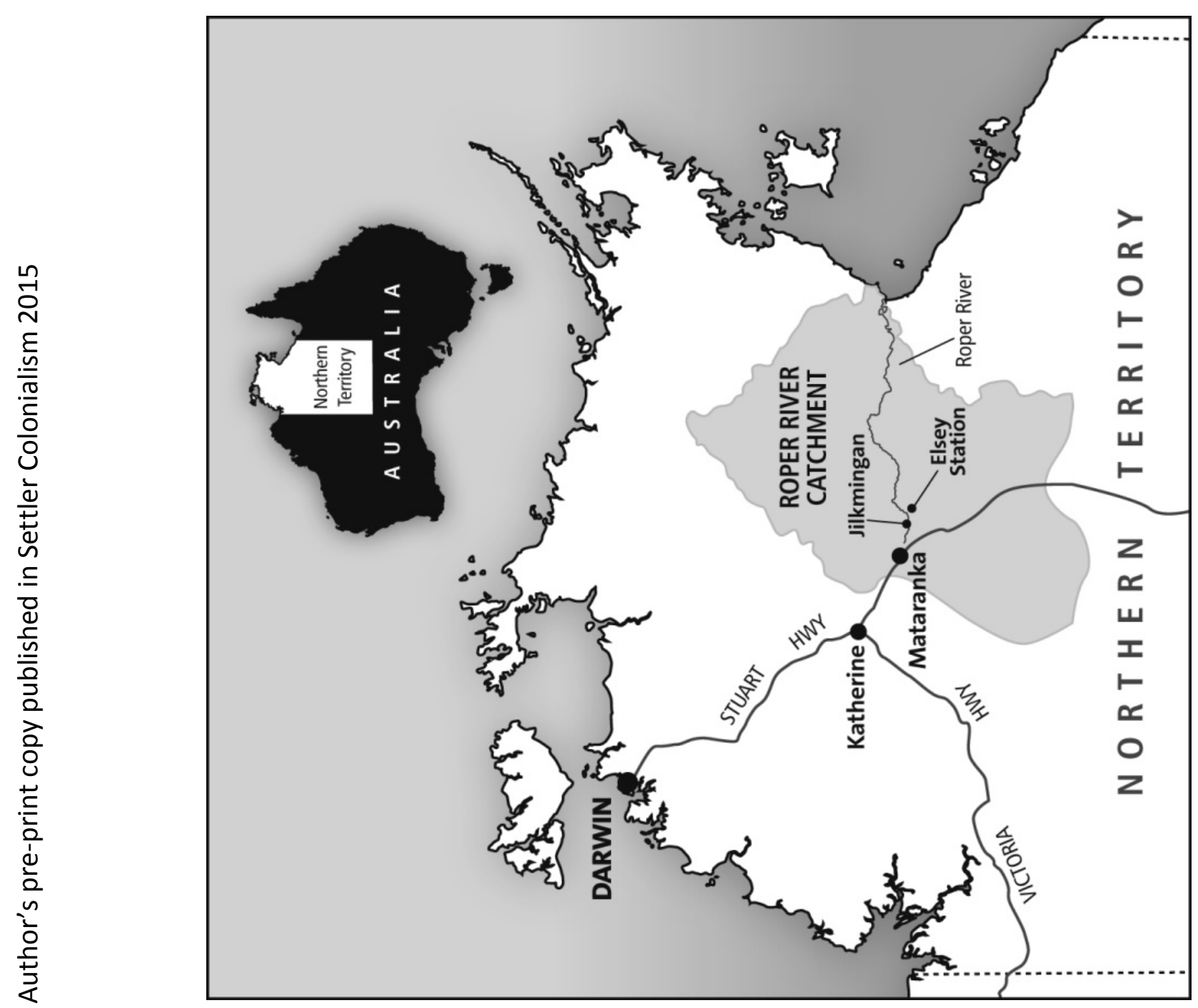




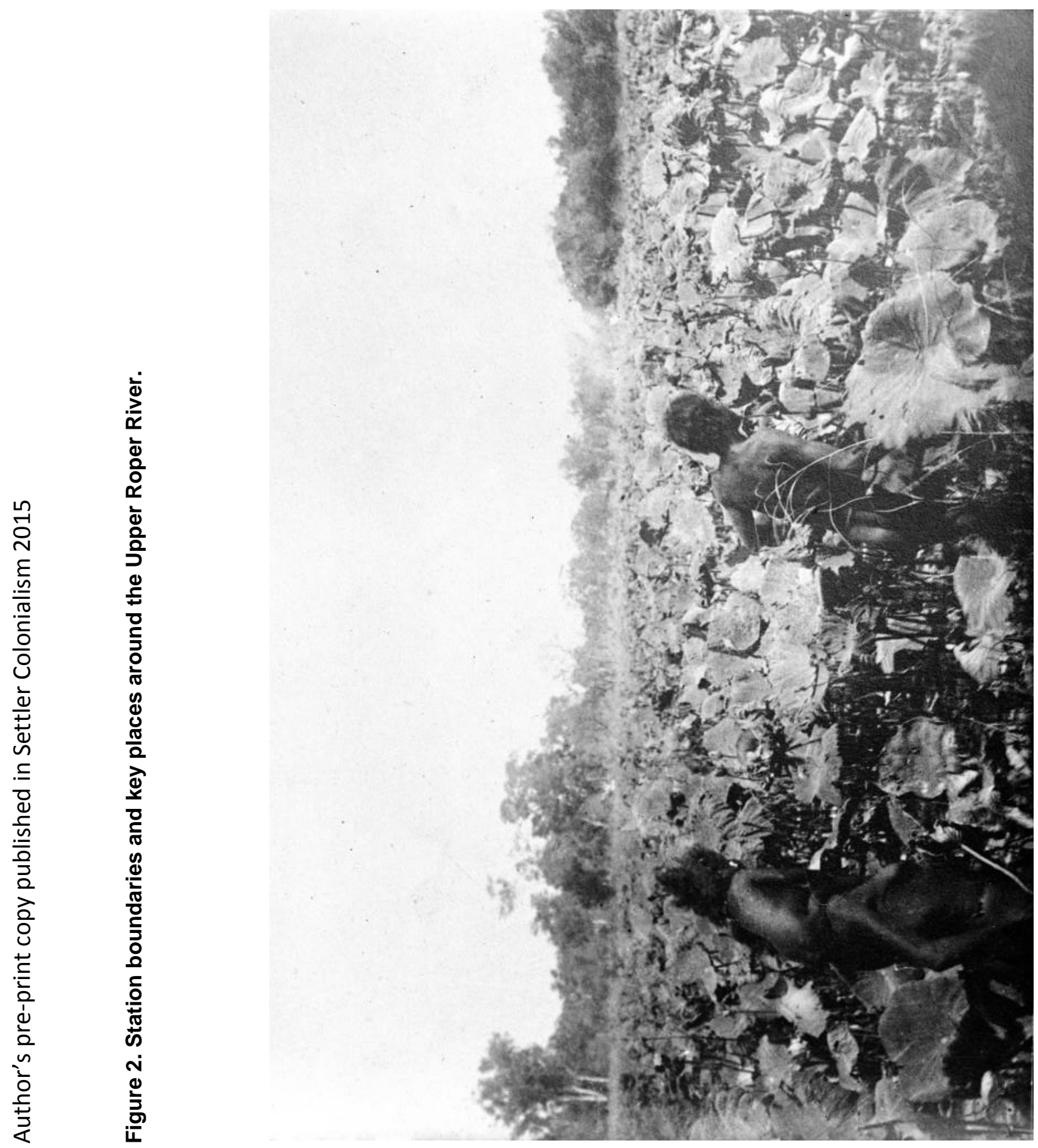



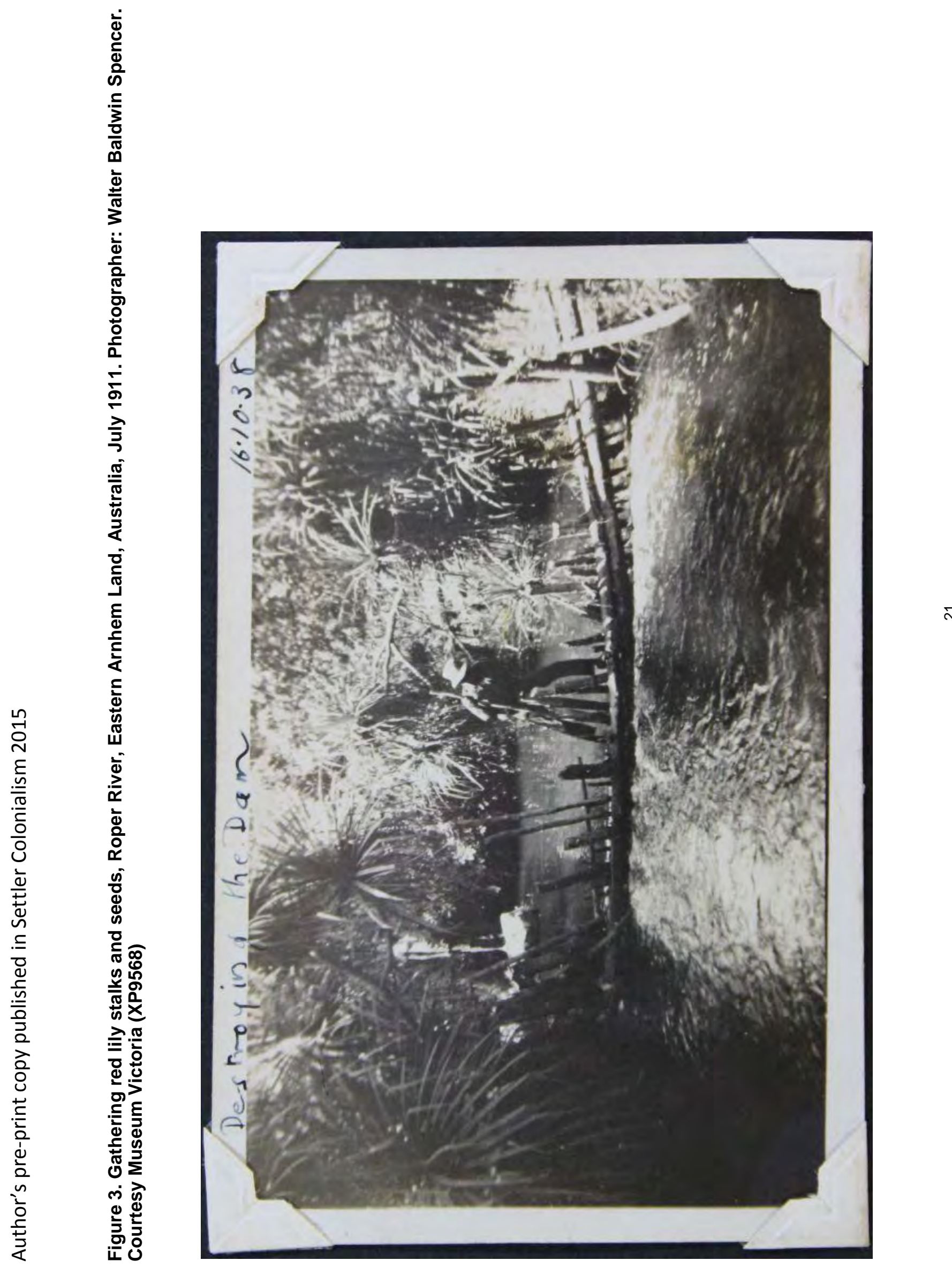


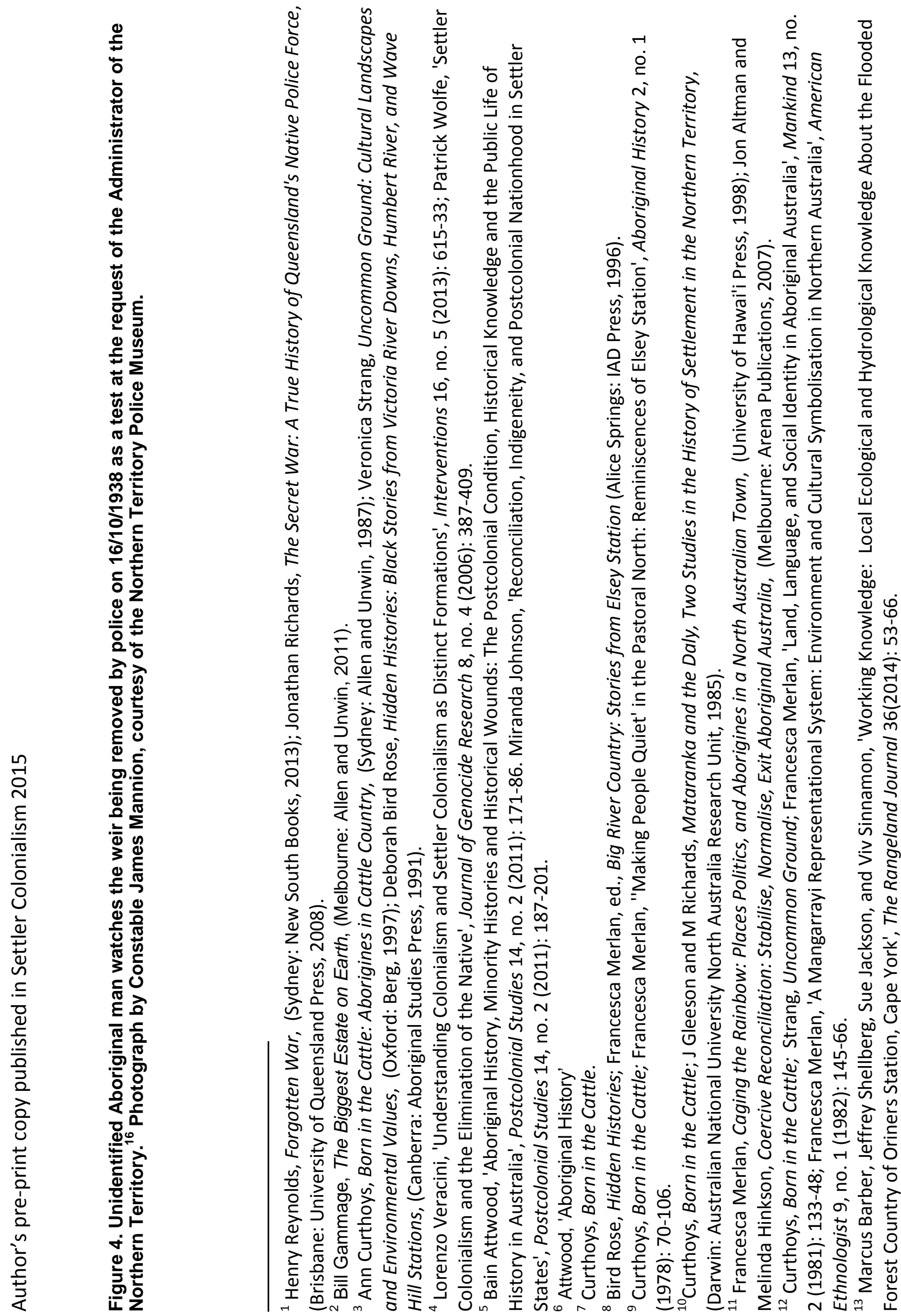

N 


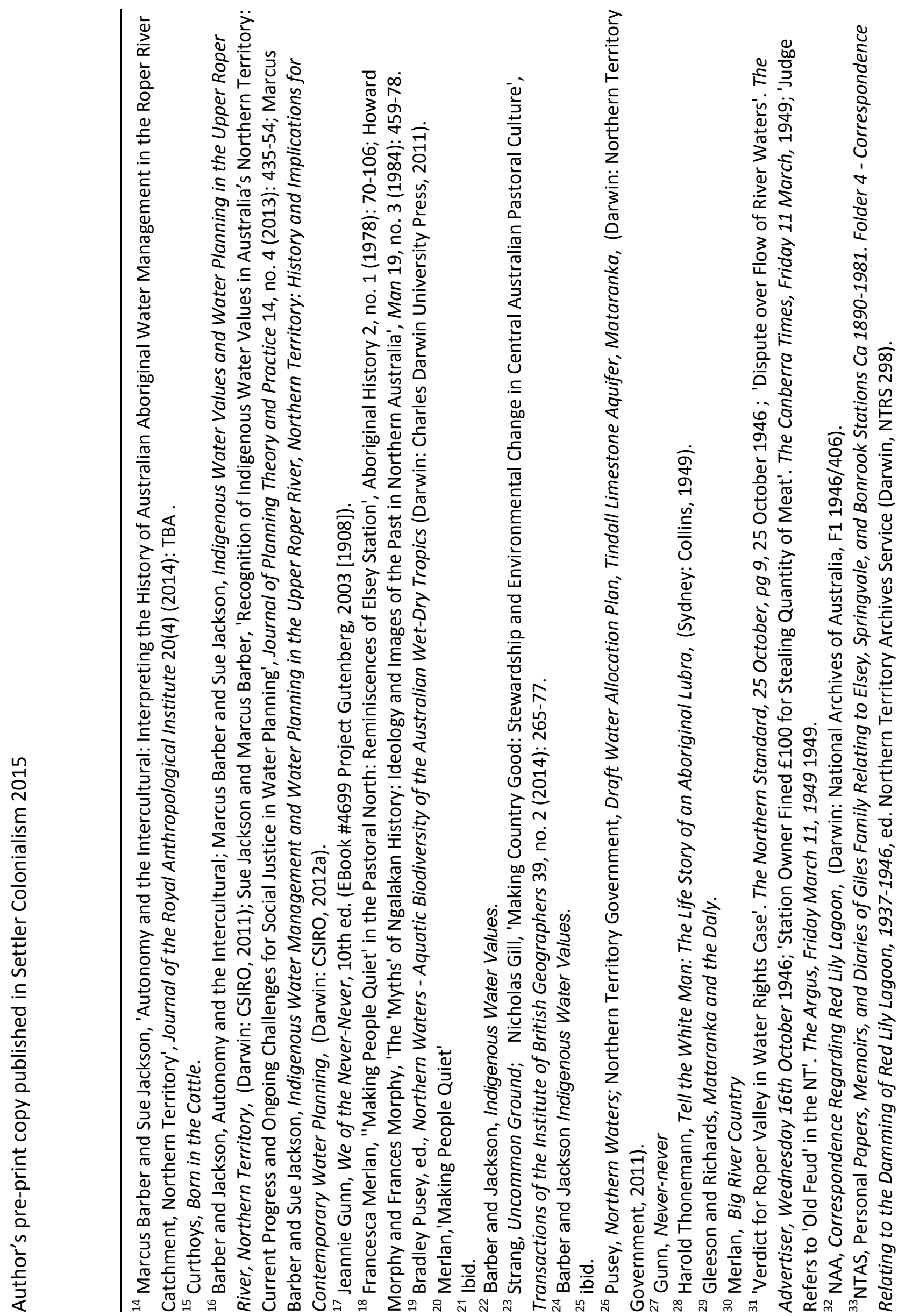




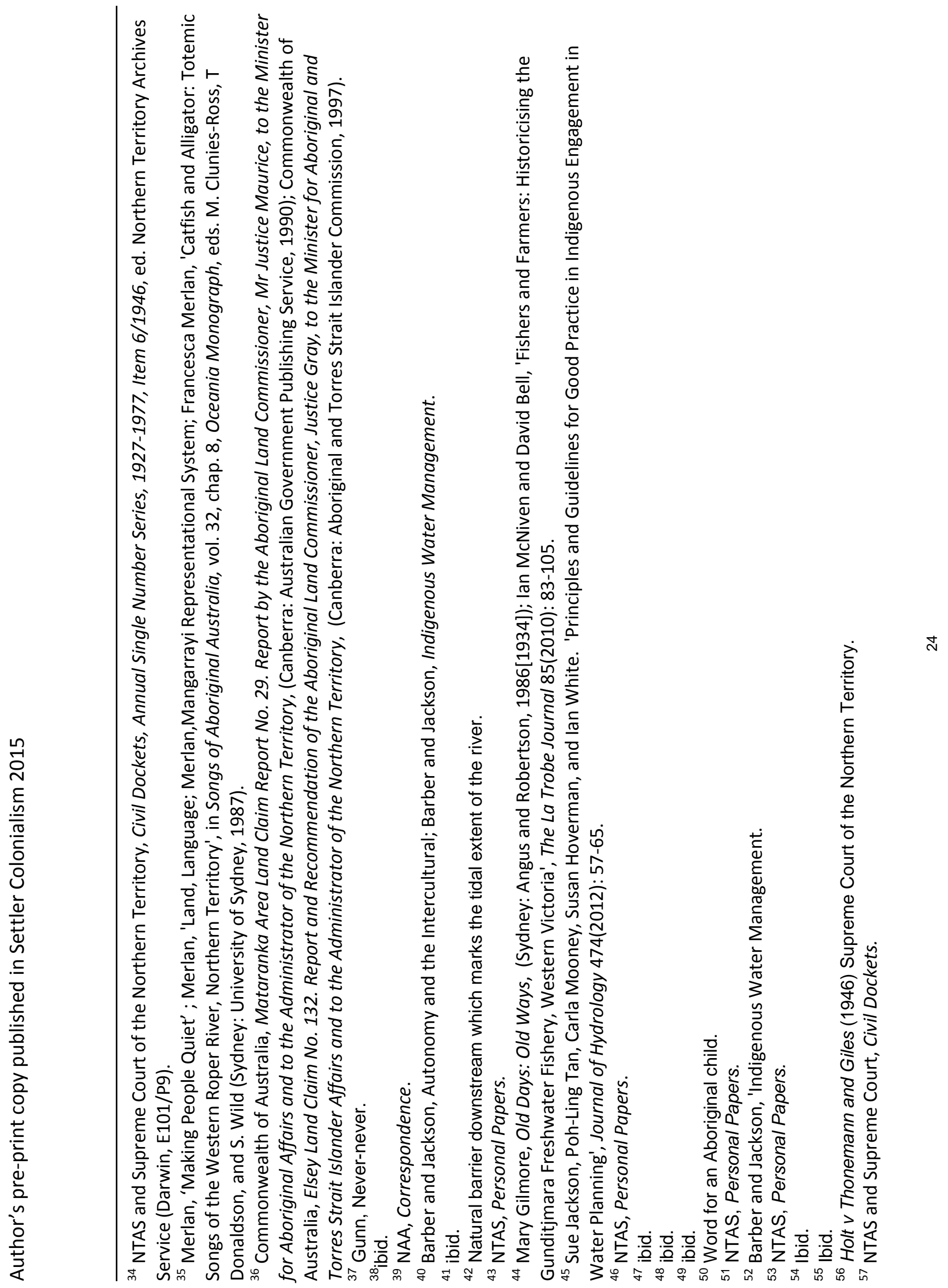




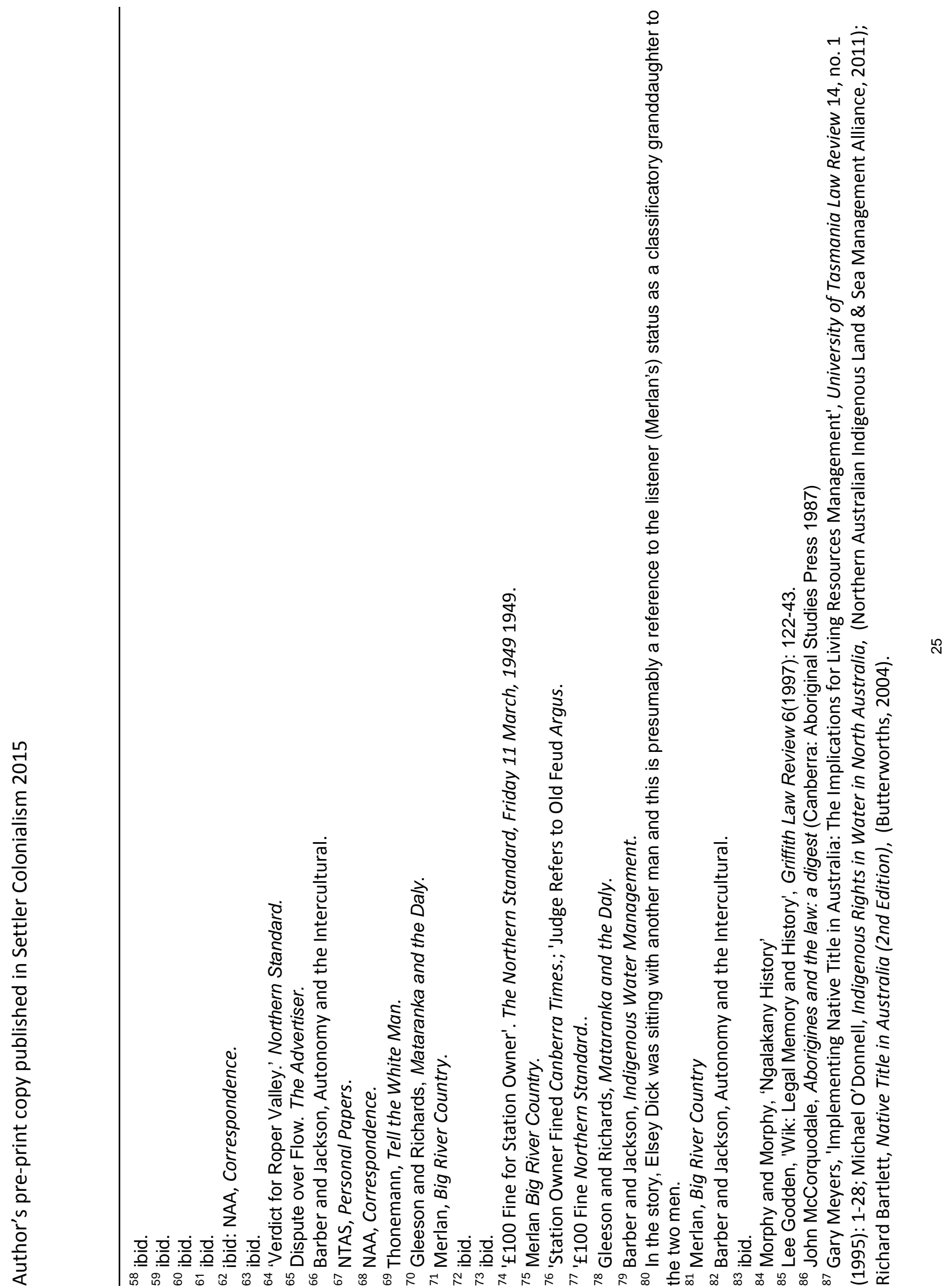




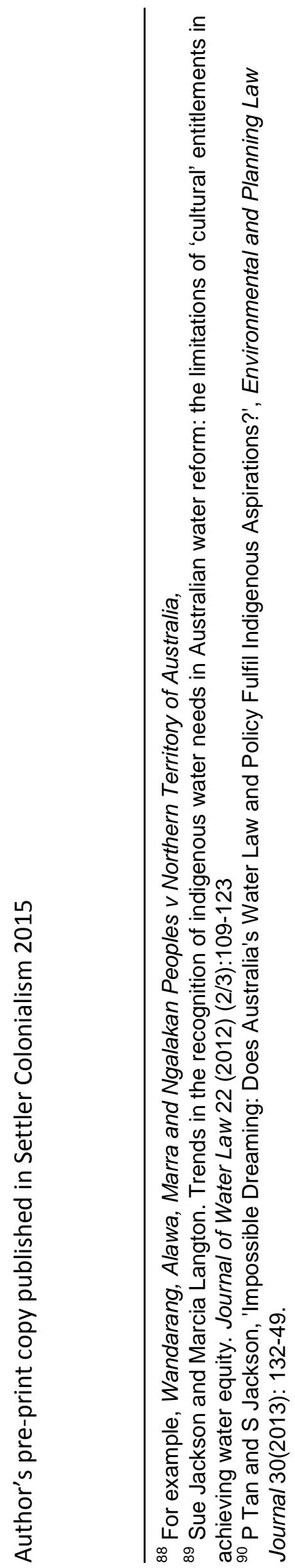

